\title{
The dream of Charles Bonnet (1720-1793)
}

By Olivier Rieppel

\section{Introduction}

Charles Bonnet of Geneva was a leading spokesman against the rise of materialistic philosophies during the Age of the French Enlightment. Together with Albrecht von Haller and Lazzaro Spallanzani he supported preformationism to counter atomistic theories of generation proposed by Georges Buffon, John Turberville Needham and Pierre-Louis Moreau de Maupertuis. These latter authors tried to explain embryogenesis by the juxtaposition of parts derived from seminal fluids of both sexes, a process that would be governed only by the laws of movement and by the contingent properties of matter. In contrast to this materialistic outlook, preformationism permitted to trace the chain of causality leading up to the formation of the embryo back to the Creator as prima causa of and sufficient reason for the organization of matter.

The study of Charles Bonnet's writings shows, however, that his notion of preformation changed remarkably over the years. What he proposed was the pre-existence of the germs which God had preformed at the time of Creation. During decades he hesitated to endorse the doctrine of emboitement, implying the encapsulation of the germs within one another, or alternatively to accept the doctrine of dissémination, i.e. the universal dispersal of minute and therefore invisible germs. The experiments on spontaneous generation conducted by Buffon and Needham, reported in the second volume of Buffon's «Histoire Naturelle, générale et particulière» (Paris, 1749) and repeated by Spallanzani ${ }^{1}$, seemed to confirm the doctrine of dissémination ${ }^{2}$, as was also pointed out by Joseph-Adrien Lelarge de Lignac in his "Lettres à un Américain», published in $1751^{3}$. Further support in favour of the hypothesis of dissemination was provided by Bonnet's early speculations on the mechanism of budding as a means of reproduction and regeneration in plants ${ }^{4}$.

On the other hand, the great Malebranche had supported the doctrine of emboîtement in his "De la Recherche de la Vérité» ${ }^{5}$, and Réaumur's experiments on regeneration in crustaceans pointed in the same direction ${ }^{6}$, as did Bonnet's own work on the regeneration of the limbs in urodeles ${ }^{7}$. The analogy of preformation with insect metamorphosis further added to the 
plausibility of the theory of emboitement ${ }^{8}$, as did Haller's studies on the development of the $\operatorname{chick}^{9}$. Finally, Bonnet's theory on palingenesis rendered the emboîtement of the germs of resurrection a logical necessity ${ }^{10}$ and thus led Bonnet to a refinement of the doctrine of encapsulated germs in his "Mémoire sur les Germes»"11. But what exactly were the germs that were created by God and encapsulated within one another?

\section{Bonnet's changing views on preformation}

In his early work ${ }^{12}$, Bonnet defended a rather figurative notion of preformation. Noting the individual variability of characters within one species, he believed that the preformed germs must vary accordingly. However, during later periods of his life, he shifted to the idea that only the "essential characteristics" of each species were preformed ${ }^{13}$. In his "Palingénésie philosophique» he wrote:

\footnotetext{
"One usually understands by this term [viz the germ] an organized being reduced to extremely small size; if it were possible to analyze it at this stage, one would find it to share the same essential properties, which the organized beings of its species show after their evolution. I have thus noted that it is necessary to understand the word germ in a much wider sense, what obviously emerges from my own principles. Thus this term will not only designate an organized body reduced to small size, but it will also designate all kinds of original preformation, from which a Tout organique can result as from its immediate cause" (Bonnet, 1769) ${ }^{14}$.
}

God had created the organisms each according to its species, and hence the germ must include the (eternal) idea of its form ${ }^{15}$. Still later, Bonnet expressed his views in an increasingly abstract language. Perhaps drawing on Haller's earlier views on the mechanism of epigenesis ${ }^{16}$, he stated:

"The germ is, so as to say, nothing more than a series of points which develop into lines. These lines will grow and multiply and will form surfaces ..." (Bonnet, 1769) ${ }^{17}$.

What are the circumstances that prompted Bonnet's change of mind? One point may be the critique of Abraham Trembley, the discoverer of the famous polyp (Hydra viridis), who was Bonnet's relative. Referring to the capability of the polyp to reproduce by budding, Trembley pointed out that the bud represents a simple expansion of the skin rather than a fully preformed individual ${ }^{18}$. This critique did have an effect on Bonnet as he himself admitted ${ }^{19}$. 
A second problem area which must have forced Bonnet to abandon his early views on preformation was represented by the phenomena of heredity and malformations. Did the occurrence of monsters imply that these had been originally preformed by the Creator, a view admitted by Albrecht von Haller but rejected by Bonnet? ${ }^{20}$ And if the embryo is fully preformed in the female egg, how could the mule originating from the fertilization of a mare by a male ass acquire its father's ears and voice? The problems of monstrosities and of heredity were easily explained by the atomistic epigenesists who, like Maupertuis in his "Vénus physique» (1745) and in his "Système de la Nature» (1751/1754), attributed malformations and the variable combination of paternal and maternal characteristics in the offspring to the more or less fortuitous combination of atoms contributed to generation by both male and female. Bonnet had to restrict preformation to the essential characteristics of the species and to explain problems of heredity and individual variation by accidental influences exerted on the embryo during the process of its growth and evolution.

Influenced by Haller's concept of the tela cellulosa ${ }^{21}$, Bonnet visualized the germ as to consist of a folded network of elementary fibres. Nutritive particles "coming from the outside" would be assimilated at their proper place into the meshes of the network of elementary fibres by the action of "attractive forces" and thereby cause the germ to unfold ${ }^{22}$.

Like Albrecht von Haller Bonnet held that the development of the germ would be triggered by the male semen which would stimulate the heart-beat of the foetus ${ }^{23}$. Bonnet deserted his friend, however, when he postulated that the male seminal fluid would also constitute the first nutritive material for the germ ${ }^{24}$. This hypothesis helped him to explain sexual dimorphism and the inheritance of paternal characteristics in hybrids within the context of ovism. The organs of the embryo were believed to grow by the assimilation of nutritive molecules which would selectively match the various types of tissues. These molecules would be extracted from the blood, the bloodvessels acting as sieves or filters ${ }^{25}$. Bonnet conjectured that the male genital organs would contain a miniature circulatory system, mirroring that of the adult organism and capable to extract molecules from the blood which would become stored in the seminal fluid and which would determine paternal characteristics if assimilated to the germ. The male semen would thus be capable to imprint paternal characteristics on the germ whose essential parts were preformed in the female egg. 
Since Haller had refuted Buffon's claim that a female seminal fluid is secreted from the corpus luteum ${ }^{26}$, Bonnet conjectured that the same mechanism which would enable the male genital organs to capture molecules determining paternal characteristics would also allow the germ to capture molecules determining individual maternal characteristics from the female blood. By these hypotheses Bonnet believed to have solved all problems of heredity and individual variation, but evidently he could not avoid coming close to the logic of the atomists' claim that the foetus forms by the juxtaposition of particles derived from male and female seminal fluids which in turn derive from a superabundance of nutritive material contained in the blood $^{27}$.

The occurrence of malformations was explained by Bonnet having recourse to accidental causes which would influence the preformed germ so as to produce monstres par excès or monstres par défaut ${ }^{28}$. This again represents a move away from pure preformationism which would necessitate the assumption of originally preformed monstres. With his theory on the origin of monstrosities Bonnet introduced a chance factor into the process of embryogenesis which again was an element of the otherwise so severely criticized logic of atomistic epigenesis.

\section{The dream of Charles Bonnet}

Over the years Bonnet moved away from a figurative to a rather abstract notion of preformation, and as his view on the origin and evolution of organized beings changed, he approached the logic of atomistic preformation as supported in particular by Buffon and Maupertuis. Still, he never became tired to attack the views of these authors because he considered them to pave the way for atheism. Several factors have been identified as to be responsible for Bonnet's changing views, but an additional and perhaps most influential factor has become identifiable through the publication of the correspondence between Albrecht von Haller and Charles Bonnet by Otto Sonntag. In a letter dated 4 November 1754 , Bonnet communicated the contents of a dream to Albrecht von Haller which dealt with the problem of generation $^{29}$.

This letter dates from a period when Haller had not yet performed his observations on the development of the chick which along with other factors would eventually convert him back to preformationism in $1757^{30}$. Bonnet 
had been meditating the problem of generation and felt close to a solution when he fell asleep. A man appeared in his dream, dessed all in black and holding a scalpel in one hand (not specified whether right or left) and a cylindrical mirror in the other. The man approached a corps and started to dissect the genitals (of unspecified sex). These disclosed a confusing labyrinth of vessels and tubules, the complexity of which transcended the powers of human imagination. The "anatomist" addressed Bonnet as a mortal being of great curiosity and ignorance, and informed him of the fact that the embryo is at first in a fluid state, being secreted from the complicated network of genital vessels and tubules which would organize this fluid and imprint on it the foetus' proper form. The master realized that his disciple did not understand the lesson and asked him to look at the miraculous labyrinth of genital vessels through the cylindrical mirror. Bonnet was amazed to discover in this mirror the image of a complete foetus, designed in all its details and with great precision. He was just about to ask the great man a number of questions when his dream vanished.

Having recounted his dream, Bonnet immediately associated it with Buffon's theory on generation ${ }^{31}$, what shows that this dream of the archpreformationist had a compensatory function. In fact it can be said that the dream anticipated the later development of Bonnet's thought. The master, dressed in black and appearing immortal, did not accept Bonnet's dogmatic views on preformation. It is conceivable that this dream-figure also incorporated projected elements of Albrecht von Haller's personality. Bonnet admired Haller as a great empirical scientist of immortal fame, who could and in fact did provide important guidelines and constraints for the abundant and sometimes perhaps exuberant flow of ideas generated by Bonnet's mind.

The two principal elements of Bonnet's later thinking that were anticipated in this dream are the idea that germ represents the foetus in a generalized and distorted manner, and the importance of the pattern of the blood-vessels in the genital organs and in the germ respectively.

During the 18th century, people were fond of drawings of distorted figures which became recognizable only when viewed in a particularly shaped mirror. In a similar way, human perception would not recognize the foetus if it became visible in its first germinal condition ${ }^{32}$. And just as the appearance of the embryo changes during its development, which constitutes a series of metamorphoses or révolutions, so does the outward appearance of the species change in the course of its palingenesis: 
" $\ldots$ it would be impossible for us to recognize a horse, a chicken, a snake, if we could see them in their first form, in the form they had at the time of their creation" (Bonnet, $1769)^{33}$.

The second point concerning the rôle which the pattern of blood circulation in the male genitals and in the female germ respectively plays in the process of the latter's evolution has been dealt with above. It is again foreshadowed in the dream which shows the form of the embryo to be determined by the labyrinth of vessels and tubules in the genital organs. This idea, with the implication of a male and female seminal fluid, was first hinted at in chapter six of the first volume of "Considérations sur les Corps Organisés» which, according to Bonnet, draws on the manuscript "Méditations sur l'Univers» composed in the years following his first reading of Leibniz" "Théodicée» during winter 1748. The dream, triggered by Bonnet's search for a mechanism explaining heredity, thus has had immediate consequences, or reflects Bonnet's thoughts on these matters in an unadorned manner, i. e. as leaning towards atomistic epigenesis. In chapter seven of the second volume of the "Considérations» Bonnet revised his theory, now rejecting the notion of female seminal fluids following the discoveries of Haller.

\section{Bonnet's personality}

In view of the compensatory function of the dream, the latter may also tell us something about Bonnet's personality. Bonnet was a very conservative and deeply religious person. His adherence to the doctrine of preformation, supported by the philosophy of Leibniz must have been influenced by the theological notion of predestination that became so important in Calvinistic thought ${ }^{34}$. His never ending attacks on the views of Buffon, Maupertuis and their allies were motivated by his aversion against materialism. Materialism suspended God from his function as first cause of and sufficient reason for the process of generation, and thus opened the door to an atheistic interpretation of the phenomena observed in nature on the basis of empiricism. At the same time, the materialists of the French Enlightment were a driving force of progressive political movements.

Bonnet's staunch opposition against materialism, atheism and political renovation are well known and documented in his «Mémoires autobiographiques» as well as in his correspondence with Albrecht von Haller. In his dream, the unconscious expressed a compensatory attitude towards Bonnet's 
conscious morale. His view of life, one of a rigidly preformed creation, predetermined from the beginning, was grounded in a theologically motivated conservatism dominant in a city bearing the stamp of Calvinism, and it was designed to exclude all accidental causes, spontaneity and change ${ }^{35}$. But this is exactly what Bonnet came to accept, albeit projected into the problem of generation, under the influence of a dream-figure which characteristically wore the black garments of a pastor or of an official dignitary. Haller, who seems to have preferred brown clothing, proved more orthodox by his claim of originally preformed malformations and by his rejection of Bonnet's hypothesis that the male seminal fluid would serve as first nutrient for the developping germ. Yet, Bonnet's notion of cosmological change, as expressed in his «Palingénésie philosophique» (1769) remained as paradoxical as Leibniz' optimism which had impressed him so much on the occasion of his first reading of the "Theodicy» ${ }^{36}$. Drawing on Augustinian neoplatonism all change that was experienced by human beings in time and space was considered to have been foreordained in the eternal world of Divine ideas. Even if Bonnet thus became a leading albeit paradoxical exponent of a temporalized view of nature ${ }^{37}$, he could, however, never overcome his "natural aversion against democracy". ${ }^{38}$

\section{Anmerkungen}

${ }^{1}$ Castellani, C. (ed.), Lettres à M. l'Abbé Spallanzani de Charles Bonnet, p. 148-149, Milano 1971.

2 See also Bonnet, C., Considérations sur les Corps Organisés, seconde édition, Vol. I, p. 101, Amsterdam 1768.

${ }^{3}$ Roger, J., Les Sciences de la Vie dans la Pensée Française du XVIII ${ }^{e}$ Siècle, p.697, Paris 1971.

${ }^{4}$ Bonnet, C., Considérations..., Vol. I, p. 228-230; 1768.

5 Savioz, R. (Ed.), Mémoires autobiographiques de Charles Bonnet de Genève, p. 92, 100, Paris 1948. Bonnet was impressed by Malebranche's statements on insects and preformation, but he did not accept the latter's occasionalism.

${ }^{6}$ Bonnet, C., Considérations..., Vol. II, p. 36-37; 1768.

${ }^{7}$ Bonnet, C., $I I^{D}$ Mémoire sur la Reproduction des Membres de la Salamandre Aquatique, in Euvres d'Histoire Naturelle et de Philosophie de Charles Bonnet, édition in-8, Vol.XI, p. 114-115, Neuchâtel 1781.

${ }^{8}$ Bonnet, C., Considérations..., Vol. I, p. 43; 1768. See also Bonnet, C., Contemplation de la Nature, Vol. I, p.285-286, Amsterdam, 1764.

${ }^{9}$ Haller, A.v., Sur la Formation du Cœur dans le Poulet..., Lausanne, 1758. See also Bonnet, C., Considérations..., Vol. I, p. 108; 1768. Bonnet, C., Contemplation..., Vol. I, p. 165; 1764. 
${ }^{10}$ Bonnet, C., La Palingénésie philosophique, Vol. I, p. 206, 274-283, Genève 1769.

${ }^{11}$ Bonnet, C., Mémoire sur les Germes, in Euvres, éd. in-8, Vol. X, p. 1-17, Neuchâtel 1781.

12 Bonnet, C., Considérations..., Vol. I, p. 38-39; 1768. Chapter V of the Considérations is based on the manuscript entitled «Méditations sur l'Univers» which Bonnet wrote during the years 1748-1753, following his first reading of Leibniz" "Theodicy": see Savioz, R., (Ed.), Mémoires autobiographiques..., p. 100-101; 1948.

${ }^{13}$ Bonnet, C., Contemplation..., Vol. I, p. xxviii-xxix, 249; 1764.

14 Bonnet, C., Palingénésie..., Vol. I, p. 362; 1769.

${ }^{15}$ Bonnet, C., II ${ }^{D}$ Mémoire sur la Reproduction des Membres..., in CEuvres, éd.in-8, Vol. XI, p. $137 ; 1781$.

${ }^{16}$ Roe, S.A., Matter, Life, and Generation. Eighteenth-Century Embryology and the HallerWolff-Debate, p. 24, Cambridge 1981.

17 Bonnet, C., Considération..., Vol. II, p. 253-254; 1768.

${ }^{18}$ Castellani, C. (Ed.), Lettres..., p. 38-40; 1971.

19 Bonnet, C., Contemplation..., Vol. I, p. 249; 1764.

${ }^{20}$ Sonntag, O. (Ed.), The Correspondence between Albrecht von Haller and Charles Bonnet, p. 476-498, Berne 1983. Letters exchanged during the period from 12 Febr. 1766 to 27 May 1766.

${ }^{21}$ Sonntag, O. (Ed.), Correspondence..., p. 83; 1983.

22 Bonnet, C., Considérations..., Vol.I, p.56-57; 1768. See also Bonnet, C., Palingénésie..., Vol. I, p. 87-88; 1769.

${ }^{23}$ Bonnet, C., Considérations..., Vol. II, p. 195; 1768.

${ }^{24}$ Bonnet, C., Considérations..., Vol. II, p.207-209. See also Bonnet, C., Palingénésie..., Vol. I, p. $89 ; 1769$. L. Bourguet, in his Lettres Philosophiques sur la Formation des Sels et des Crystaux et sur la Génération \& le Méchanisme Organique des Plantes et des Animaux, p. 149-152, Paris 1729, expressed similar views, but was not cited by Bonnet in this context.

25 Bonnet, C., Considérations..., Vol. I, p. 58; 1768.

${ }^{26}$ Bonnet, C., Considérations..., Vol. II, p. 220; 1768.

${ }^{27}$ Gaskin, E.B., Investigations into Generation, p.127, Baltimore 1967. With this theory Bonnet comes particularly close to Buffon's theory on generation as expounded in the second volume of his Histoire Naturelle (Paris, 1749).

${ }^{28}$ Bonnet, C., Considérations..., Vol. II, p. 244-279; 1768.

29 Sonntag, O. (Ed.), Correspondence..., p. 54-55; 1983.

${ }^{30}$ Roe, S.A., Matter, Life, and Generation..., p.26; 1981. See also Sonntag, O. (Ed.), Correspondence ..., p. 109-110, 776; 1983.

${ }^{31}$ Sonntag, O. (Ed.), Correspondence ..., p. 55; 1983.

32 Bonnet, C., Considérations..., Vol. II, p. 252; 1768.

33 Bonnet, C., Palingénésie..., Vol. I, p. 258; 1769.

${ }^{34}$ Hoffheimer, M. H., Maupertuis and the eighteenth-century critique of preexistence. In Journal of the History of Biology 15 (1982), p. 119-144. See also Barber, W. H., Leibniz in France. From Arnauld to Voltaire. A study in French Reactions to Leibnizianism, 1670-1760, p. 10-17, Oxford 1955.

${ }^{35}$ Marx, J., Charles Bonnet contre les Lumières 1738-1850. In: Studies on Voltaire and the Eighteenth Century 156 and 157 (1976), p. 145.

36 Savioz, R. (Ed.), Mémoires autobiographiques..., p. 100-101; 1948. 
${ }^{37}$ Lovejoy, A. O., The Great Chain of Being, 15 ${ }^{\text {th }}$ printing, Cambridge (Mass.) 1982.

${ }^{38}$ Savioz, R. (Ed.), Mémoires autobiographiques..., p. 145; 1948.

\section{Zusammenfassung}

Der Wandel von Charles Bonnets Auffassung der Präformation der Keime wird aufgrund seiner Schriften erörtert. Es zeigt sich, daß ein Traum, den Bonnet in einem Brief vom 4. November 1754 seinem Freund Albrecht von Haller mitteilte, wesentliche Punkte von Bonnets späteren Anschauungen vorausnahm. Die Bedeutung des Traumes zur Analyse von Bonnets Persönlichkeit wird kurz gestreift.

PD Dr. Olivier Rieppel

Paläontologisches Institut und Museum

der Universität Zürich

Künstlergasse 16

CH-8006 Zürich 